\title{
SELECTIVE IN VIVO DAMAGE BY 'VISIBLE' LIGHT OF BrdU-CONTAINING \\ MITOCHONDRIAL DNA IN A THYMIDINE KINASE-DEFICIENT MOUSE CELL LINE WITH PERSISTENT MITOCHONDRIAL ENZYME ACTIVITY
}

B. CROIZAT* AND G. ATTARDI

Division of Biology, California Institute of Technology, Pasadena, Califormia 91125, U.S.A.

\section{SUMMARY}

The selective incorporation of 5 -bromodeoxyuridine (BrdU) into mitochondrial DNA (mit-DNA) in the $\mathrm{LM}\left(\mathrm{TK}^{-}\right) \mathrm{ClID}_{\mathrm{D}}$ cell line, a thymidine kinase-deficient derivative of $\mathrm{L}$ fibroblasts with persistent mitochondrial enzyme activity, has been utilized to specifically damage mit-DNA by 'visible' light irradiation. ('Visible light' indicates the source of light used, although the components most active photochemically on BrdU-substituted DNA are in the near-visible range, $300-340 \mathrm{~nm}$.) (Szybalski \& Opara-Kubinski, 1965).

$\mathrm{LM}\left(\mathrm{TK}^{-}\right) \mathrm{Cl} \times \mathrm{D}$ cells, which had been grown in the presence of $30 \mu \mathrm{g} / \mathrm{ml} \mathrm{BrdU}$, were irradiated with 'visible' light. Analysis of the pre-existing mit-DNA in these cells, which had been long-term labelled with $\left[5^{3} \mathrm{H}\right]$ deoxycytidine, showed a progressive decrease, with increasing duration of irradiation, in the proportion of the closed-circular form and an increase in that of the open-circular form of mit-DNA, with the subsequent appearance of fragments of this DNA. Furthermore, there was a decrease during irradiation in the total amount of mit-DNA, which became about $35 \%$ of the non-irradiated control after 65 h irradiation. On the other hand, irradiation with 'visible' light failed to cause any quantitative or qualitative change, with respect to the non-irradiated control, in mit-DNA from cells grown in the absence of $\mathrm{BrdU}$ and long-term labelled with $\left[\mathrm{Me}^{3} \mathrm{H}\right]$ thymidine.

An analysis of the incorporation of $\left[5^{-3} \mathrm{H}\right]$ deoxycytidine into mit-DNA of BrdU-grown cells, during a 3 -h exposure of the cells to the precursor following irradiation, showed a fairly rapid decline of mit-DNA labelling; this became about $50 \%$ of the non-1rradiated control after $\mathrm{i} 2 \mathrm{~h}$ irradiation, decreasing to about $25 \%$ in the next $48 \mathrm{~h}$. By contrast, no effect of irradiation was observed on the subsequent pulse-labelling of mit-DNA with $\left[M e-{ }^{3} \mathrm{H}\right]$ thymidine in cells grown in the absence of BrdU. Furthermore, no change in the size of the extracted nuclear DNA was found in irradiated BrdU-grown cells.

The progressive and selective damage and destruction of mit-DNA during irradiation with 'visible' light of $\mathrm{Cl}$ I D cells correlate fairly well with the kinetics of loss of cell viability occurring under the same conditions, as described in the accompanying paper, strongly suggesting a link between the two phenomena.

- Present address: Biochimie Cellulaire, Collège de France, Paris Cedex 05, France. 


\section{INTRODUCTION}

As shown in the accompanying paper (Attardi, Keeley \& $\mathrm{Tu}$, I975), $\mathrm{Cl}$ I D cells grown in the presence of 5 -bromodeoxyuridine (BrdU) exhibit a specific loss of viability when exposed to 'visible' light, with a half-life of about $8 \mathrm{~h}$. The evidence obtained indicates that this killing effect of 'visible' light irradiation does not depend on the presence of $\mathrm{BrdU}$ in the medium during irradiation, but requires the previous exposure of the cells to the halogenated precursor; furthermore, the sensitivity to light is about one order of magnitude higher than expected from any possible residual incorporation of BrdU into nuclear DNA of $\mathrm{Cl}$ I D cells. The involvement of mitochondrial DNA (mit-DNA) in this killing effect of 'visible' light was strongly suggested by the above results. In the present paper, this possibility has been directly investigated by examining the effects of 'visible' light irradiation both on the integrity and the replication of mit-DNA of $\mathrm{Cl} r \mathrm{D}$ cells grown in the presence of $\mathrm{BrdU}$. It has been found that there are, during irradiation, progressive damage and destruction of mit-DNA, which correlate fairly well with the kinetics of loss of cell viability, strongly suggesting a link between the 2 phenomena.

\section{MATERIALS AND METHODS}

\section{Cells and methods of growth}

Reference is made to the accompanying paper (Attardi et al. 1975) for the conditions of growth of $\mathrm{LM}\left(\mathrm{TK}^{-}\right) \mathrm{Cl}_{\mathrm{I}} \mathrm{D}$ cells (dialysed calf serum was used in all experiments). Except where otherwise specified, the concentration of the cells grown on solid substrate was not allowed to exceed $5 \times 10^{8}$ cells per 10-cm Petri dish (10 ml of medium) or $250-\mathrm{ml}$ Falcon Plastic tissue culture bottle ( $30 \mathrm{ml}$ of medium).

\section{Labelling conditions}

Pulse labelling of mit-DNA was carried out in most cases directly on the irradiated cultures (and the corresponding non-irradiated controls); in a few experiments, these cultures were trypsinized, replated at $3.5-5 \times 10^{6}$ cells/10-cm Petri dish and incubated for $24 \mathrm{~h}$ in a $37{ }^{\circ} \mathrm{C}$ incubator before pulse labelling. In both procedures, $\mathrm{Cl}$ ID cells maintained in the presence of $\mathrm{BrdU}(3 \circ \mu \mathrm{g} / \mathrm{ml})$ were exposed for $3 \mathrm{~h}$ to $\left[5^{-5} \mathrm{H}\right]$ deoxycytidine $(2 \mathrm{I} \cdot 2 \mathrm{mCi} / \mu \mathrm{mol} ;$ i० $\mu \mathrm{Ci} / \mathrm{ml})$, while cells maintained in the absence of the halogenated precursor were exposed for the same length of time to $\left[\mathrm{Me}^{3} \mathrm{H}\right]$ thymidine $(40.3 \mathrm{mCi} / \mu \mathrm{mol} ; 10 \mu \mathrm{Ci} / \mathrm{ml})$. Long-term labelling of mit-DNA in cells to be subsequently irradiated was carried out in bottles, by exposing for $60 \mathrm{~h}$ to $\left[5^{-}{ }^{3} \mathrm{H}\right]$ deoxycytidine or $\left[M e-^{3} \mathrm{H}\right]$ thymidine (in both cases, $4 \mu \mathrm{Ci} / 250 \mathrm{ml}$ bottle, added 5 times at $12-h$ intervals; initial cell concentration $=5 \times 10^{5}$ cells/bottle) cells maintained in the presence and, respectively, absence of BrdU. Cells to be used as an internal standard to correct for variations in yield of mit-DNA were labelled in spinners with $\left[2-{ }^{14} \mathrm{C}\right]$ thymidine $(62 \mu \mathrm{Ci} / \mu \mathrm{mol}, 0.02 \mu \mathrm{Ci} / \mathrm{ml})$ for $36-48 \mathrm{~h}$, and mixed, in constant amount in each experiment ( $\mathrm{I}$ or $2 \mathrm{ml}$ of packed cells), with the samples of $\left[5^{-3} \mathrm{H}\right]$ deoxycytidine or $\left[\mathrm{Me}^{-} \mathrm{H}\right]$ thymidinelabelled, irradiated or non-irridiated cells.

\section{Irradiation experiments}

Unlabelled cells to be irradiated were plated in $250-\mathrm{ml}$ tissue culture bottles at a concentration of $2-4 \times 10^{6}$ cells/bottle (unless otherwise specified), kept in a $37{ }^{\circ} \mathrm{C}$ incubator for $24 \mathrm{~h}$, and then exposed to 'visible' light for variable lengths of time $(7-65 \mathrm{~h})$, under the conditions detailed in the accompanying paper (Attardi et al. 1975; Puck \& Kao, 1967). Long-term 
labelled cells growing in bottles were incubated for $6 \mathrm{~h}$ in isotope-free medium (to deplete the isotope from the mitochondrial precursor pool) before being irradiated. Cultures to be used as non-irradiated controls were covered with aluminium foil and placed close to the illuminated ones.

\section{Extraction and analysis of mitochondrial $D N A$}

The ${ }^{3} \mathrm{H}$-labelled cells were detached from the dishes or bottles by trypsinization at $37{ }^{\circ} \mathrm{C}$ for 5-10 min, washed with $0.01 \mathrm{M}$ phosphate buffer $(\mathrm{pH} 7.0), 0.16 \mathrm{M} \mathrm{NaCl}$, and, in the case of the pulse-labelling experiments, counted in a haemocytometer. The cells from each experimental point were mixed with a constant amount of ${ }^{14} \mathrm{C}$-labelled spinner-grown carrier cells. After removing two $0.1-\mathrm{ml}$ samples from each mixed cell suspension (these were precipitated with $5 \%$ trichloroacetic acid, and the precipitates collected on Millipores and counted in a scintillation spectrometer: this allowed normalization of the ${ }^{3} \mathrm{H}$ data for variations in the amount or degree of labelling of the ${ }^{14} \mathrm{C}$-labelled cells added to the ${ }^{3} \mathrm{H}$-labelled cells (see below)), the cells were centrifuged down and swollen in hypotonic buffer $\left(10^{-2} \mathrm{M}\right.$ Tris buffer, $\mathrm{pH} 6.7$ $\left(25^{\circ} \mathrm{C}\right), 10^{-2} \mathrm{M} \mathrm{KCl}, 10^{-4} \mathrm{M}$ EDTA) for $45 \mathrm{~min}$. Homogenization and differential centrifugation were carried out as previously described (Attardi \& Attardi, 1972). The mitochondrial pellet was finally resuspended in $0.25 \mathrm{M}$ sucrose, $0.01 \mathrm{M}$ Tris buffer, $\mathrm{pH} 6.7, \mathrm{1}^{-4} \mathrm{M}$ EDTA $(5 \mathrm{ml}$ per $\mathrm{ml}$ of the original volume of packed cells). Total mit-DNA was extracted from the pellet by a modification of the procedure by Smith, Jordan \& Vinograd (197I), as previously detailed (Storrie \& Attardi, 1972), and separated from degraded nuclear DNA by centrifugation through a 2-step $\mathrm{CsCl} /$ ethidium bromide gradient $\left(\mathrm{I} \mathrm{ml} \mathrm{CsCl}, \rho=1 \cdot 76\right.$ or $1 \cdot 70 \mathrm{~g} \mathrm{~cm}^{-3}$ (depending on whether the material was from cells grown in the presence or absence of BrdU); $3 \mathrm{ml} \mathrm{CsCl}, \rho=1.40 \mathrm{~g} \mathrm{~cm}^{-3}$, in $0.01 \mathrm{M}$ Tris buffer, $\mathrm{pH} 7.4,0.01 \mathrm{M} \mathrm{EDTA,} \mathrm{with} 100 \mu \mathrm{g} / \mathrm{ml}$ ethidium bromide) in the Spinco SW65 rotor at $38000 \mathrm{rev} / \mathrm{min}$ for $5 \mathrm{~h}$. About 50 fractions were collected from the bottom of the gradient on Whatman $3 \mathrm{MM}$ filters, washed batch-wise with $5 \%$ trichloroacetic acid and then with ethanol, and counted in a scintillation counter. The separation of the various forms of mit-DNA in the 2-step $\mathrm{CsCl}$ /ethidium bromide gradients used in this work depends in part on sedimentation velocity differences in part on buoyant density differences.

\section{Extracted and analysis of total cell DNA}

Total DNA of Cl ID cells was extracted by a modification of the Marmur's procedure (196I), as detailed in the accompanying paper (Attardi et al. 1975), and analysed in a $\mathrm{CsCl}$ density gradient, by using a $\mathrm{CsCl}$ solution of density of $1.70 \mathrm{~g} \mathrm{~cm}^{-3}$ and centrifuging for 3 days in a Spinco $\mathrm{SW}_{39}$ rotor at $31000 \mathrm{rev} / \mathrm{min}$.

\section{Normalization of results}

The data on the recovery of ${ }^{5} \mathrm{H}$-labelled mit-DNA in the 2-step $\mathrm{CsCl} /$ ethidium bromide gradients were normalized ( $\mathrm{I}$ ) in the pulse-labelling experiments, for differences in the amount of cells labelled in different samples, as estimated on the basis of the cell count; (2) in all the experiments, for differences in recovery of mit-DNA due to variations in cell breakage and in the following steps, on the basis of the recovery of ${ }^{14} \mathrm{C}$-labelled mit-DNA from the internal standard. For the latter purpose, the ${ }^{14} \mathrm{C}$ data were first corrected for possible differences in the amount or degree of labelling of the ${ }^{14} \mathrm{C}$-labelled cells added to the ${ }^{3} \mathrm{H}$-labelled cells before homogenization.

- The expression '2-step $\mathrm{CsCl} /$ ethidium bromide gradient' is used in this paper to indicate its initial form; during the centrifugation, a linear gradient becomes established by diffusion. 


\section{RESULTS}

Effect of cell concentration on BrdU incorporation into mitochondrial DNA

The incorporation of $\mathrm{BrdU}$ into mit-DNA of $\mathrm{Cl} \mathrm{ID}$ cells appears to depend strictly on their physiological state. In particular, we have observed a striking effect of the cell density on the capacity of the cells to utilize the halogenated precursor. Up to a

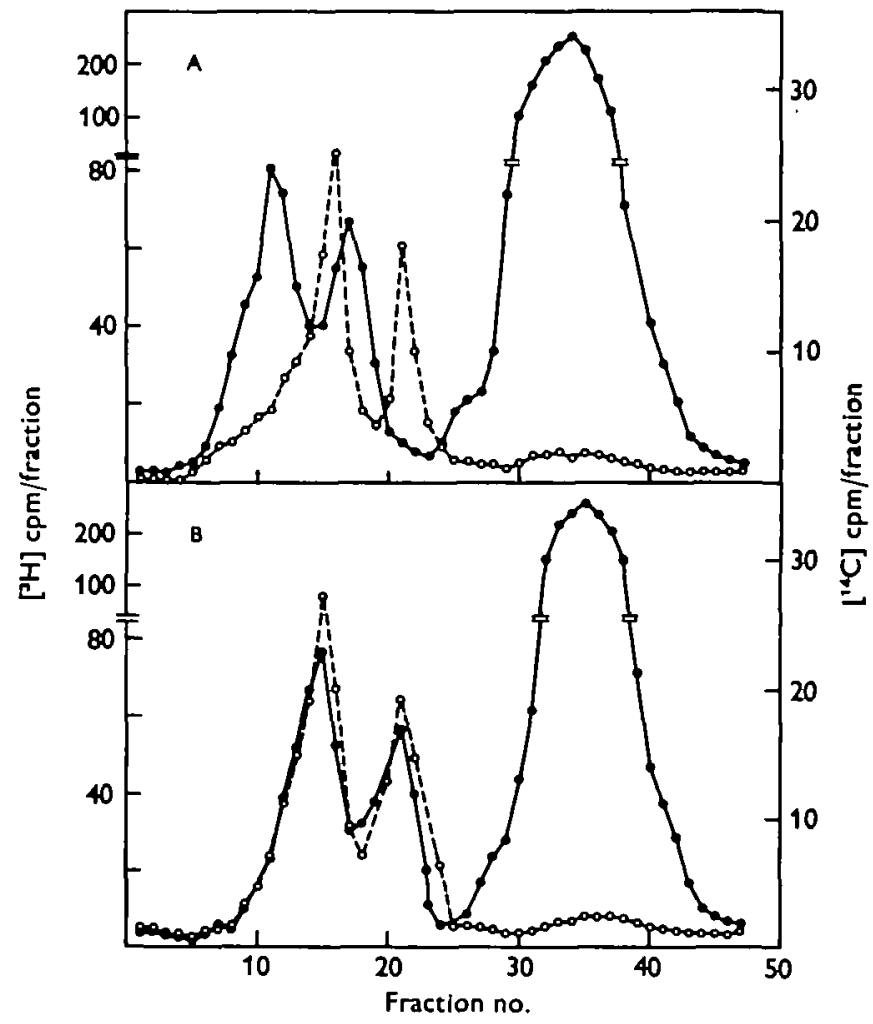

Fig. I. Effect of cell density during growth of $\mathrm{LM}\left(\mathrm{TK}^{-}\right) \mathrm{Cl}$ ID cells on their subsequent incorporation of BrdU into mit-DNA. $\mathrm{LM}\left(\mathrm{TK}^{-}\right) \mathrm{Cl}$ I D cells removed from a high density (A) or low density stock culture (B) (both maintained in the presence of $\mathrm{BrdU}$ ) were labelled for $3 \mathrm{~h}$ with $\left[5^{-3} \mathrm{H}\right]$ deoxycytidine, in the presence of the halogenated precursor, at a concentration of about $5 \times 10^{\circ}$ cells/bottle. See text for details. - 1 , profiles in 2-step $\mathrm{Cs}$ Cl-ethidium bromide gradients of $\left[5^{3} \mathrm{H}\right]$ deoxycytidine pulse-labelled mit-DNA; $\mathrm{O}-\mathrm{O}$, profiles of $\left[2-{ }^{14} \mathrm{C}\right]$ thymidine long-term labelled mit-DNA from carrier cells grown in the absence of BrdU.

concentration of $5 \times 10^{6}$ cells $/ 10-\mathrm{cm}$ Petri dish, the incorporation of BrdU into mitDNA is maximal, or near-to-maximal, as judged from the displacement of this mitDNA with respect to light mit-DNA in the 2-step $\mathrm{CsCl} /$ ethidium bromide gradient; at a concentration of about $10^{7}$ cells/Petri dish, the incorporation of BrdU is already appreciably decreased. This effect of the cell density persists even after the cells from a concentrated stock have been diluted to a concentration which would normally be suitable to give maximal incorporation of BrdU. Fig. I A shows the pattern 
in a 2-step $\mathrm{CsCl}$ /ethidium bromide gradient of $\left[{ }^{3} \mathrm{H}\right]$ deoxycytidine pulse-labelled mitDNA from $\mathrm{Cl}$ ID cells maintained in the presence of $\mathrm{BrdU}$, which were removed from a stock culture at a concentration of $5 \times 10^{6}$ cells/dish and transferred into a $250-\mathrm{ml}$ bottle in amount adequate to give a concentration of about $5 \times 10^{6} \mathrm{cells} / \mathrm{bottle}$ at the time of the $\left[{ }^{3} \mathrm{H}\right]$ deoxycytidine pulse. One recognizes in the ${ }^{3} \mathrm{H}$ profile the 2 peaks of form I (closed-circular), closer to the bottom, and form II (open-circular)

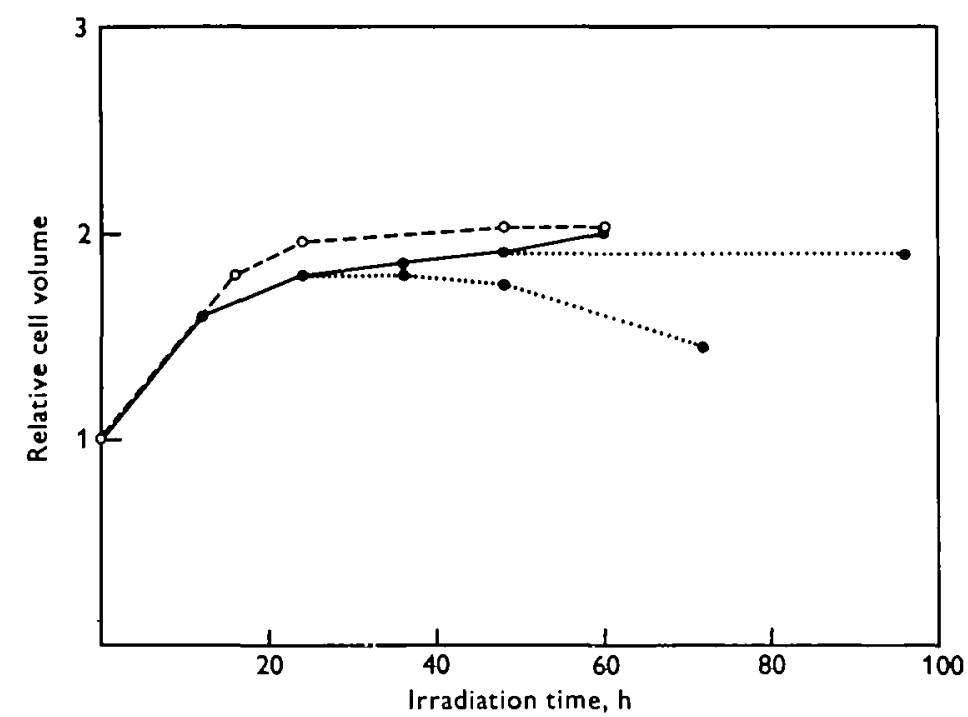

Fig. 2. Effect of 'visible' light irradiation on cell size of $\left.\mathrm{LM} \mathrm{TK}^{-}\right) \mathrm{Cl}$ ID cells maintained in the presence or absence of BrdU. -O, cells exposed to light for different lengths of time in the presence of BrdU; $\cdots$, cells exposed to light for either 24 or $48 \mathrm{~h}$ in the presence of BrdU, and then trypsinized, replated at $5 \times 10^{8}$ cells/ bottle in BrdU-containing medium and incubated for different lengths of time in the dark; $O_{--.}$, cells exposed to light for different lengths of time in the absence of BrdU.

of mit-DNA, and an upper band of degraded nuclear DNA (Storrie \& Attardi, 1972). (The shoulder(s) on the faster-sedimenting side of form I in this and other patterns in the present paper presumably consist(s) of partially or fully closed concatenated dimers and higher oligomers, and of closed circular dimers; these complex forms of mitDNA have all been shown to occur in the parental L cells (Nass, 1969) and probably exist also in $\mathrm{LM}_{\left(\mathrm{TK}^{-}\right)} \mathrm{Cl}_{\mathrm{I}} \mathrm{D}$ cells.) The 2 peaks of mit-DNA appear to be considerably displaced towards the denser side with respect to the corresponding peaks of $\left[{ }^{14} \mathrm{C}\right]$ thymidine-labelled mit-DNA from carrier $\mathrm{Cl} \mathrm{ID}$ cells grown in the absence of BrdU. Fig. I B shows the results of a parallel experiment, in which the cells were removed from a stock culture at $2 \cdot 1 \times 10^{7}$ cells/dish and pulse-labelled with $\left[{ }^{3} \mathrm{H}\right]-$ deoxycytidine at a concentration of $5 \times 10^{8}$ cells/bottle. One can see that the $\left[{ }^{3} \mathrm{H}\right]-$ deoxycytidine-labelled mit-DNA components almost coincide in position with the light $\left[{ }^{4} \mathrm{C}\right]$ thymidine-labelled mit-DNA components, indicating very little, if any, incorporation of $\mathrm{BrdU}$, during the $\left[{ }^{3} \mathrm{H}\right]$ deoxycytidine pulse and at least 2 cell generations preceding the pulse, in the cells derived from the high-density stock. 


\section{Effect of 'visible' light irradiation on cell size}

As shown in the accompanying paper (Attardi et al. 1975), exposure to 'visible' light slows down considerably the growth of $\mathrm{Cl}$ ID cells maintained both in the presence and in the absence of BrdU, the effect being somewhat more marked in BrdUmaintained cells. In the present work, the slowing down of cell growth has been found to be accompanied by an increase in the average cell size, which became about double in $24 \mathrm{~h}$, augmenting only slightly thereafter (Fig. 2). This increase in size, which points to some block of cell division, indicates that the increase in overall cell mass of the $\mathrm{Cl}$ I D cell cultures during exposure to light is greater than estimated from cell number, approximating in the first $24 \mathrm{~h}$ that of the non-irradiated cultures. After trypsinization and replating, the average size of the $24 \mathrm{~h}$-irradiated BrdU-grown $\mathrm{Cl}$ ID cells gradually decreased towards its normal value; no such decrease in size was observed in the $48 \mathrm{~h}$-irradiated BrdU-grown cells, presumably because after this time of irradiation the majority of cells are no longer viable.

\section{Effect of 'visible' light irradiation on integrity of mitochondrial DNA}

The $\mathrm{Cl}$ I D cells used in these experiments had been long-term labelled with $\left[5^{-3} \mathrm{H}\right]-$ deoxycytidine or $\left[\mathrm{Me}^{-3} \mathrm{H}\right]$ thymidine (depending on whether they were grown in the presence or absence of $\mathrm{BrdU}$ ) before irradiation. Analysis in 2-step $\mathrm{CsCl} /$ ethidium bromide gradients of the mit-DNA from $\mathrm{Cl} I \mathrm{I}$ cells grown and irradiated in the presence of BrdU, after different periods of irradiation (Fig. $3^{\mathrm{A}-\mathrm{E}}$ ), shows progressive quantitative and qualitative changes in this DNA. In comparison with the profile of mit-DNA from the non-irradiated culture (Fig. $3 \mathrm{~A}$ ), it appears that during irradiation there is a continuous decrease in the amount of labelled mit-DNA (which becomes about $35 \%$ of the non-irradiated control value after $65 \mathrm{~h}$ ) (Fig. $3 \mathrm{E}$ ); furthermore, there is progressive distortion of the profile leading to a decrease in the proportion of component $I$ and to the appearance of material in the trough between components I and II and on the slower sedimenting side of component II, and finally to a flattened distribution of the labelled components (Fig. $3 \mathrm{E}$ ). It should be noticed that quantitative (about $10 \%$ decrease), and qualitative changes in mit-DNA are already noticeable at the earliest point examined, i.e., after $18 \mathrm{~h}$ of irradiation (Fig. $3 \mathrm{~B}$ ). It seems likely that the labelled material on the slower sedimenting side of component II represents fragments of mit-DNA, while the material in the trough between the 2 components presumably represents fully relaxed concatenated oligomers or fragments of circular dimers.

In contrast to the situation described above for $\mathrm{Cl}$ ID cells grown in the presence of BrdU, irradiation for $65 \mathrm{~h}$ of cells grown in the absence of BrdU does not affect either quantitatively or qualitatively the pattern of their mit-DNA (Fig. $3 \mathrm{G}$ ), as compared to the mit-DNA of the non-irradiated cells (Fig. $3 \mathrm{~F}$ ). 


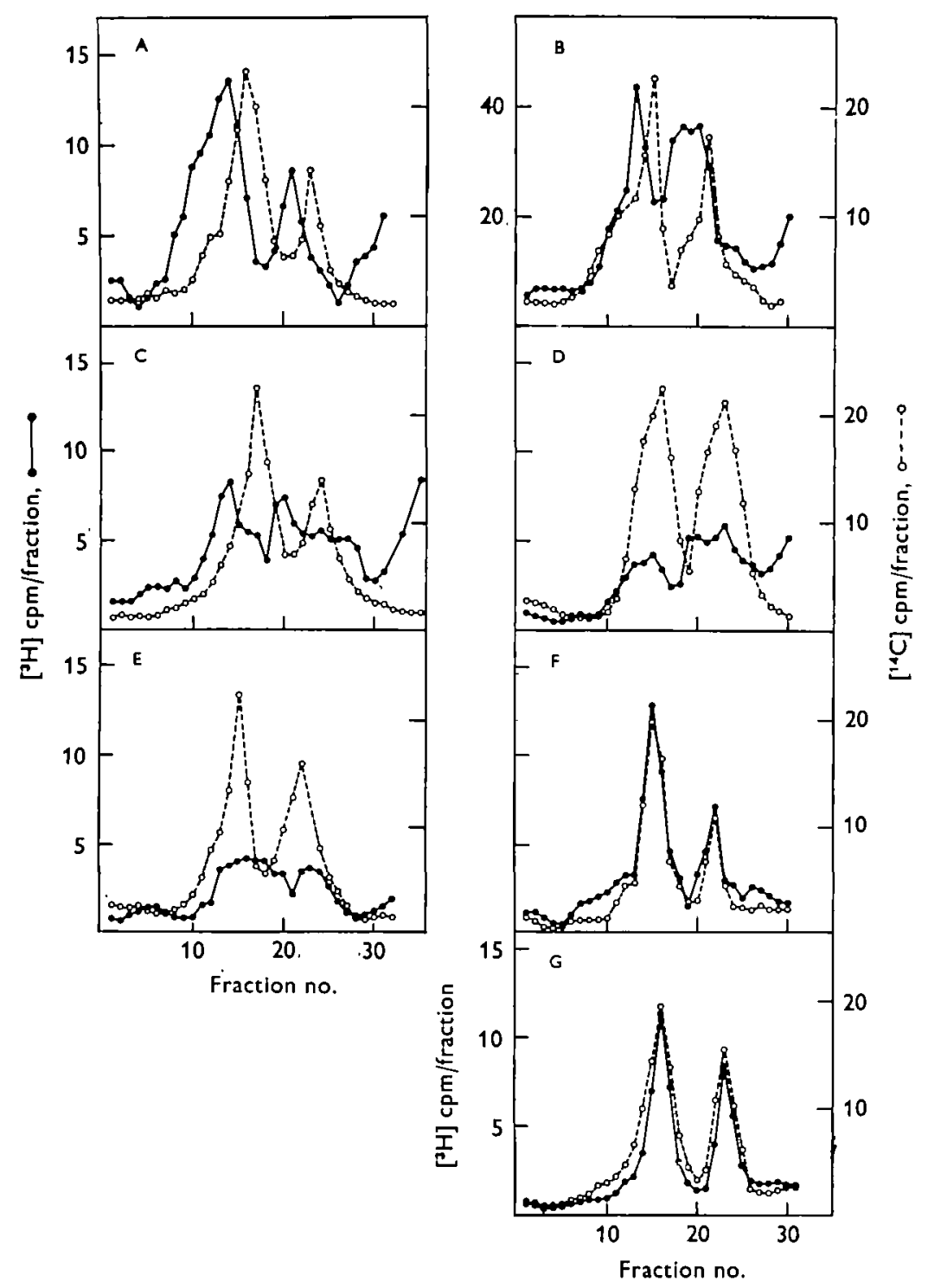

Fig. 3. Effect of 'visible' light irradiation on the integrity of mit-DNA of LM(TK-) $\mathrm{Cl}$ i D cells grown in the presence or absence of BrdU. Equal samples of $5 \times 10^{5}$ cells were plated in $25^{\circ}-\mathrm{ml}$ bottles in BrdU-containing or BrdU-free medium and labelled for $60 \mathrm{~h}$ with $\left[5^{-}{ }^{3} \mathrm{H}\right]$ deoxycytidine or $\left[\mathrm{Me}^{3} \mathrm{H}\right]$ thymidine, respectively; after further 6-h incubation in the same type of medium without radioactive precursor, the cultures were either irradiated with 'visible' light or kept covered with aluminium foil as nonirradiated controls for different lengths of time. A-E : profiles in 2-step CsCl-ethidium bromide gradients of $\left[5^{-3} \mathrm{H}\right]$ deoxycytidine long-term labelled mit-DNA from BrdUgown cells irradiated for 0 (A), I 8 (B), 30 (C), 48 (D) or $65 \mathrm{~h}$ (E); F, G: profiles of $\left[M e-{ }^{3} \mathrm{H}\right]$ thymidine labelled mit-DNA from cells grown in the absence of BrdU and irradiated for $\mathrm{O}(\mathrm{F})$ or $65 \mathrm{~h}(\mathrm{G})$. The ${ }^{3} \mathrm{H}$ radioactivity data have been normalized, as explained in Materials and methods, for differences in recovery of mit-DNA in different samples. $-\left[5^{-} \mathrm{H}\right]$ deoxycytidine or $\left[M e^{-}{ }^{3} \mathrm{H}\right]$ thymidine labelled mit-DNA; $0--O,[2-14 \mathrm{C}]$ thymidine labelled mit-DNA from carrier cells grown in the absence of BrdU. The portions of the profiles corresponding to degraded nuclear DNA are not shown. 


\section{Effect of 'visible' light irradiation on replication of mitochondrial DNA}

To examine the capacity of mit-DNA to replicate after 'visible' light irradiation of $\mathrm{Cl}$ ID cells, cells grown either in the presence or absence of BrdU were irradiated for different times $(7-60 \mathrm{~h})$, and then immediately labelled for $3 \mathrm{~h}$ with $\left[5^{-3} \mathrm{H}\right]$ deoxycytidine or, respectively, $\left[\mathrm{Me}^{3} \mathrm{H}\right]$ thymidine. As shown in Fig. 4 , the amount of pulselabelled mit-DNA from $\mathrm{Cl}$ iD cells grown in the presence of BrdU exhibits a more rapid decline, after increasing periods of irradiation, than previously described for the pre-existing long-term labelled mit-DNA. Already after 7 -h irradiation (Fig. 4B), there is an approximate $34 \%$ decrease in the amount of labelled mit-DNA relative to the mit-DNA from non-irradiated cells (Fig. $4 \mathrm{~A}$ ), and after $12 \mathrm{~h}$, a $48 \%$ decrease (Fig. 4 c.) By contrast, the qualitative changes of the labelled mit-DNA are much less pronounced than in the long-term labelling experiment. The profile of the labelled mit-DNA in 2-step $\mathrm{CsCl} /$ ethidium bromide gradients is fairly normal even after 24-h irradiation (Fig. 4D). After $48 \mathrm{~h}$, however, and even more after 60 -h irradiation (Fig. 4F), there is accumulation of labelled material in the trough between components I and II and on the slower sedimenting side of component II. Also in this experiment, the profile of mit-DNA from cells grown in the absence of BrdU and pulse-labelled after $60-\mathrm{h}$ irradiation (Fig. $4 \mathrm{H}$ ) does not show any quantitative or qualitative change with respect to the non-irradiated control (Fig. 4G).

In Fig. 5, the amount of radioactivity associated with pulse-labelled and, respectively, long-term labelled mit-DNA, in the experiments illustrated in Fig. 3 and Fig. 4, is plotted versus irradiation time. It appears that the amount of pre-existing, longterm labelled DNA remains essentially unchanged during the first $18 \mathrm{~h}$ of irradiation, and then decreases fairly rapidly to a level of about $35 \%$ of the initial value over the following $47 \mathrm{~h}$. By contrast, the amount of newly synthesized, pulse-labelled mit-DNA shows a fast decrease to a level of about $50 \%$ in the first $\mathrm{I} 2 \mathrm{~h}$, followed, in the next $48 \mathrm{~h}$, by a slower decline to a level of about $25 \%$.

In a few experiments, the capacity of the irradiated cultures, and corresponding non-irradiated controls, to synthesize mit-DNA was tested, rather than directly after irradiation, after trypsinizing the irradiated cultures and their controls, replating them at $3.5-5 \times 10^{8}$ cells/dish and incubating them for $24 \mathrm{~h}$ at $37^{\circ} \mathrm{C}$. One such experiment is shown in Fig. 6. In this experiment, and in others of this type, the level of $\left[5^{-} \mathrm{H}\right]$ deoxycytidine or $\left[\mathrm{Me}^{3} \mathrm{H}\right]$ thymidine incorporation per cell, both in the irradiated and in the non-irradiated cells, was 5-ro times lower than in the experiments in which the cultures were pulse-labelled directly after irradiation. The reason for this difference is not known, although it seems possible that it is due to precursor pool effects as a result of the trypsinization. In any case, it is clear from Fig. 6 that the quantitative and qualitative effects of irradiation on the new synthesis of mit-DNA are very similar to those observed, after the same time of irradiation, in the cultures pulse-labelled immediately after exposure to 'visible' light (compare Fig. 6 в with Fig. 4E). 


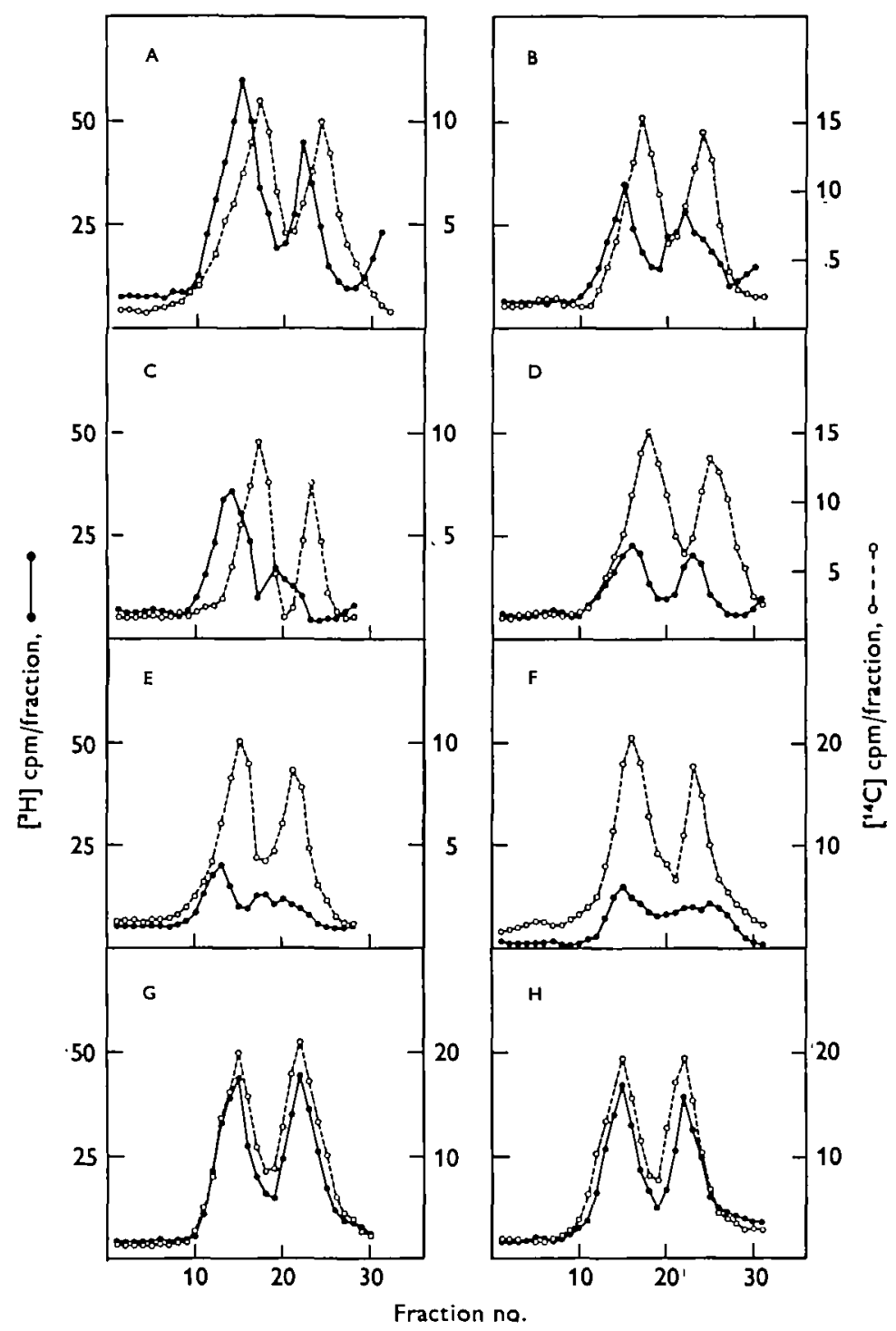

Fig. 4. Effect of 'visible' light irradiation on the replication of mit-DNA of LM(TK-) $\mathrm{Cl}$ ID cells grown in the presence or absence of BrdU. Cells were plated in $250-\mathrm{ml}$ bottles in BrdU-containing or BrdU-free medium at such a concentration that the final yield at the end of the irradiation time would not exceed $5 \times 10^{6}$ cells/bottle. After 24-h incubation in a $37^{\circ} \mathrm{C}$ incubator, the cultures were either irradiated with 'visible' light for different lengths of time or kept covered with aluminium foil as non-irradiated controls. After irradiation, the cultures were labelled for $3 \mathrm{~h}$ with either $\left[5^{-3} \mathrm{H}\right] \mathrm{deoxy}-$ cytidine (BrdU-grown cells) or [ $\left[\mathrm{Me}^{-}{ }^{3} \mathrm{H}\right]$ thymidine (cells grown in BrdU-free medium) A-F: profiles in 2-step $\mathrm{CsCl}$-ethidium bromide gradients of mit-DNA from BrdUgrown cells labelled for $3 \mathrm{~h}$ with $\left[5^{-3} \mathrm{H}\right]$ deoxycytidine after irradiation for $\circ(\mathrm{A}), 7$ (B), I 2 (C), 24 (D), 48 (E) or $60 \mathrm{~h}$ (F). G, H: profiles of mit-DNA from cells grown in the absence of $\mathrm{BrdU}$ and labelled for $3 \mathrm{~h}$ with $\left[\mathrm{Me}^{-}{ }^{3} \mathrm{H}\right]$ thymidine after o (G) or $6 \circ \mathrm{h}(\mathrm{H})$ irradiation. The ${ }^{3} \mathrm{H}$ radioactivity data have been normalized, as explained in Materials and methods, for differences in amount of labelled cells and in recovery of mit-DNA in different samples. -,$\left[5^{-3} \mathrm{H}\right]$ deoxycytidine or $\left[\mathrm{Me}^{-3} \mathrm{H}\right]$ thymidine labelled mitDNA; $O---O,\left[2-{ }^{14} \mathrm{C}\right]$ thymidine labelled mit-DNA from carrier cells grown in the absence of BrdU. The portions of the profiles corresponding to degraded nuclear DNA are not shown. 
Failure of 'visible' light to damage mit-DNA in BrdU-grown cells in the absence of incorporation of BrdU into this DNA

The above-mentioned observation that cell density during the prior growth of the cells influences strongly the extent of incorporation of BrdU into mit-DNA suggested an experiment to test whether or not the observed effects of 'visible' light can occur in BrdU-grown cells in the absence of incorporation of the halogenated precursor into mit-DNA. Fig. 7 illustrates the results of such an experiment. Here, cells

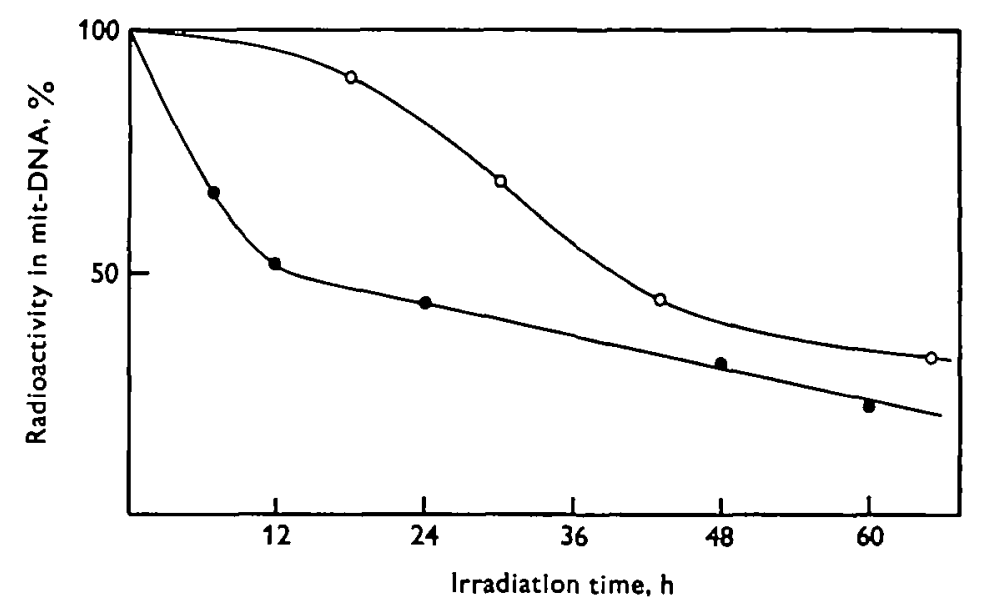

Fig. 5. Relative amount of radioactivity associated with mit-DNA in BrdU-grown $\mathrm{LM}\left(\mathrm{TK}^{-}\right) \mathrm{Cl}$ ID cells exposed to 'visible' light for different lengths of time either after long-term labelling or before 3 -h pulse-labelling with $\left[5^{-3} \mathrm{H}\right]$ deoxycytidine. The data are derived from the experiments shown in Figs. 3 and $4.0-0$, mit-DNA from cells long-term labelled before irradiation; - mit-DNA from cells pulse-labelled after irradiation.

maintained in the presence of $\mathrm{BrdU}$ and derived from a stock culture at $2.7 \times 10^{7}$ cells/Petri dish had been long-term labelled with $\left[5^{3} \mathrm{H}\right]$ deoxycytidine, under the conditions described in Materials and methods, and then irradiated for $48 \mathrm{~h} \mathrm{(Fig.} 7 \mathrm{~B}$ ) or kept covered for the same time (Fig. $7 \mathrm{~A}$ ). One can see that, as expected, the position of the ${ }^{3} \mathrm{H}$-labelled mit-DNA components from both the irradiated and the nonirradiated culture coincides with that of the ${ }^{14} \mathrm{C}$-labelled components from the carrier cells grown in the absence of $\mathrm{BrdU}$ : this indicates that, under the present conditions, very little or no incorporation of the halogenated precursor had occurred in the mitDNA of the culture long-term labelled with $\left[5^{-3} \mathrm{H}\right]$ deoxycytidine in the presence of BrdU. Furthermore, both qualitatively and quantitatively, the ${ }^{3} \mathrm{H}$ profile of the irradiated culture is indistinguishable from that of the non-irradiated culture, pointing to the absence of any light-produced damage. This result strongly suggests a link between BrdU incorporation into mit-DNA and effects on this DNA of 'visible' light irradiation. 


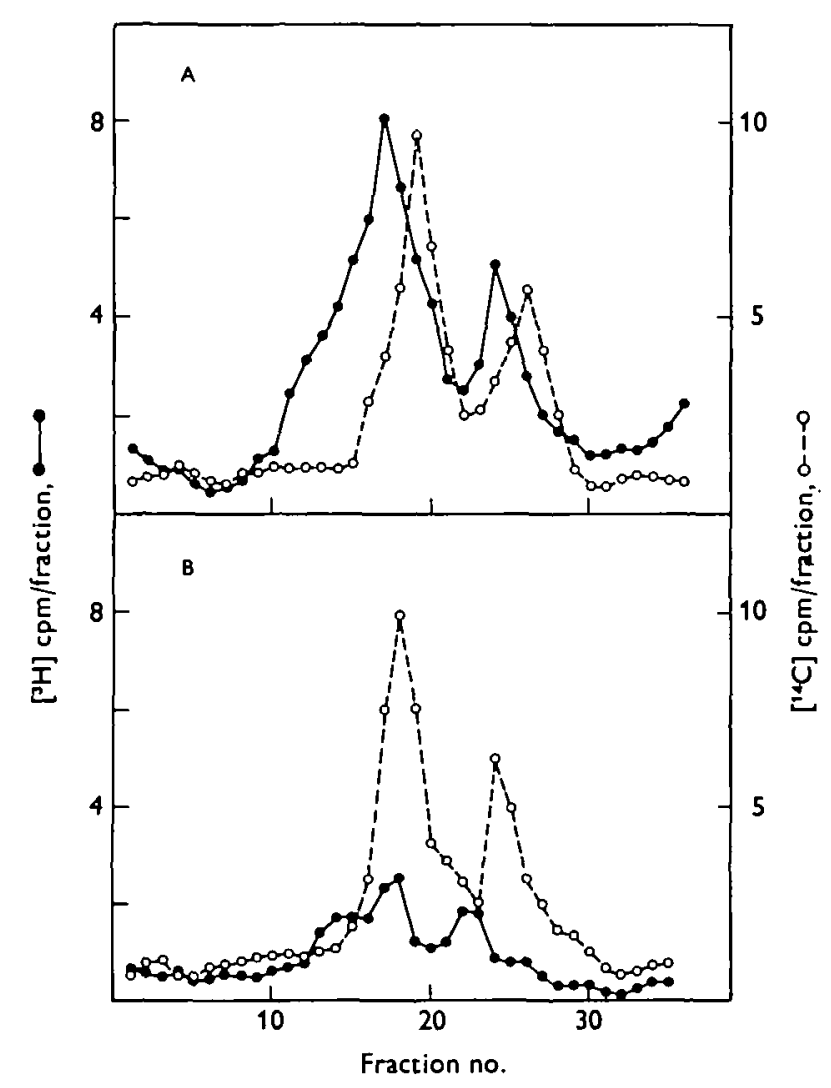

Fig. 6. Effect of 'visible' light irradiation on the replication of mit-DNA of BrdUgrown $\mathrm{LM}\left(\mathrm{TK}^{-}\right) \mathrm{Cl}$ I $\mathrm{D}$ cells, as tested by labelling for $3 \mathrm{~h}$ with $\left[5^{-3} \mathrm{H}\right]$ deoxycytidine a 48 -h irradiated culture and its non-irradiated control after trypsinization and replating. See text for details. - - , profiles in 2-step $\mathrm{CsCl}$ /ethidium bromide gradients of $\left[5^{3} \mathrm{H}\right]$ deoxycytidine pulse-labelled mit-DNA from cells irradiated for o (A) or $48 \mathrm{~h}(\mathrm{~B}) ; \mathrm{O}_{-}-\mathrm{O}$, profiles of $\left[2-{ }^{14} \mathrm{C}\right]$ thymidine labelled mit-DNA from carrier cells grown in the absence of $\mathrm{BrdU}$. Normalization of ${ }^{3} \mathrm{H}$ radioactivity data as explained in Materials and methods. The portions of the profiles corresponding to degraded nuclear DNA are not shown.

\section{Effect of 'visible' light irradiation on size of extracted nuclear DNA}

In order to examine whether 'visible' light irradiation produces any gross damage of nuclear DNA in $\mathrm{Cl}$ ID cells grown in the presence of BrdU, total cell DNA was extracted from cells which had been long-term labelled with $\left[5^{-3} \mathrm{H}\right]$ deoxycytidine and irradiated for $48 \mathrm{~h}$ and from the corresponding non-irradiated control, and analysed in $\mathrm{CsCl}$ density gradients. As shown in Fig. 8, the DNA from the 2 samples formed a sharp band of equal width in the gradients, without any indication of existence of small fragments in the sample from irradiated cells. 


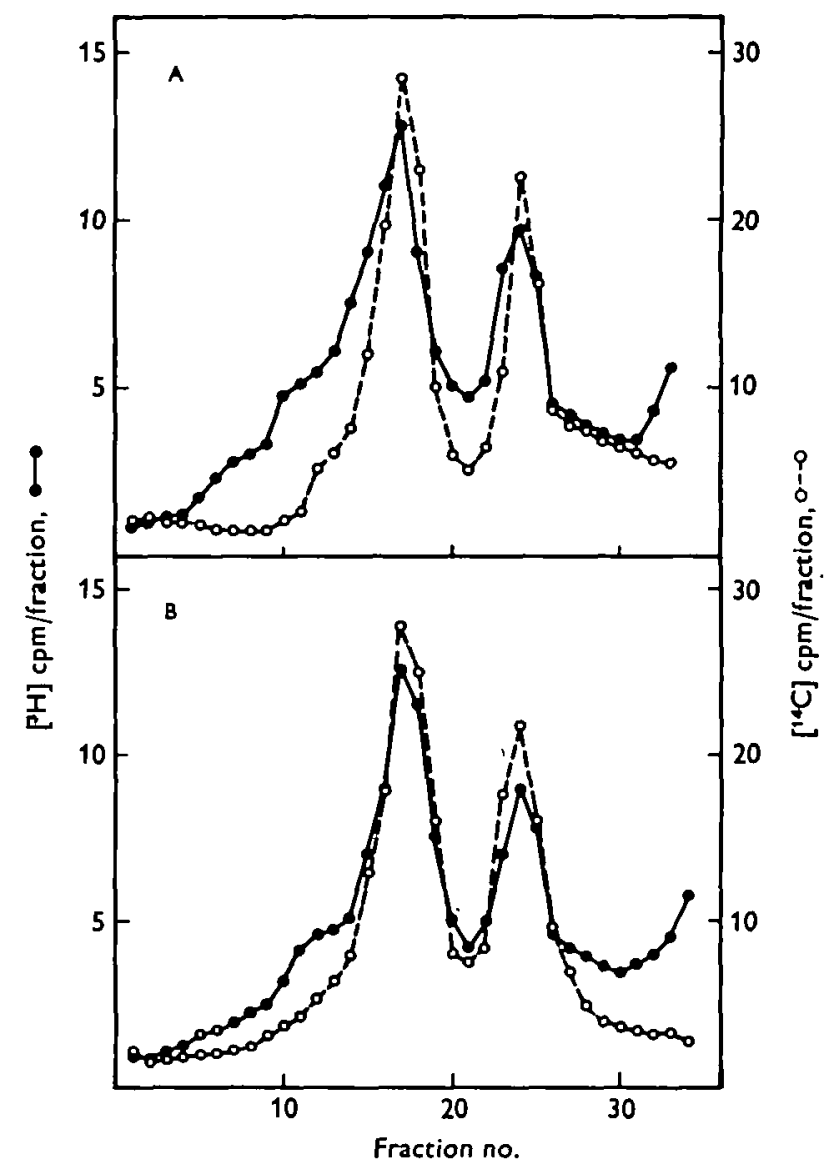

Fig. 7. Failure of 'visible' light irradiation to produce damage in 'light' mit-DNA from BrdU-grown LM(TK-) $\mathrm{Cl}$ ID cells derived from a high-density stock and longterm labelled with $\left[5^{3} \mathrm{H}\right]$ deoxycytidine in the presence of the halogenatcd precursor. Two samples of $5 \times 10^{5} \mathrm{LM}\left(\mathrm{TK}^{-}\right) \mathrm{Cl}$ i D cells derived from a stock culture at $2.7 \times 10^{7}$ cells/dish were labelled for $60 \mathrm{~h}$ with $\left[5^{-3} \mathrm{H}\right]$ deoxycytidine in BrdU-containing medium; after further 6-h incubation in the absence of the isotope, one culture was exposed to 'visible' light for $48 \mathrm{~h}$ (B), while the other was kept as non-irradiated control (A). - - , profiles in 2-step $\mathrm{CsCl} /$ ethidium bromide gradients of $\left[5^{-5} \mathrm{H}\right]$-deoxycy tidine labelled mit-DNA; $\mathrm{O}---\mathrm{O}$, profiles of $\left[2-^{14} \mathrm{C}\right]$ thymidine labelled mit-DNA from carrier cells grown in the absence of BrdU. Normalization of the ${ }^{3} \mathrm{H}$ radioactivity data as explained in Materials and methods. The portions of the profiles corresponding to degraded nuclear DNA are not shown.

\section{DISCUSSION}

\section{Influence of cell density upon BrdU incorporation into mitochondrial DNA}

Previous work had revealed a degree of substitution of thymidine by BrdU ranging from 30 to $90 \%$ in mit-DNA from an $\mathrm{LM}\left(\mathrm{TK}^{-}\right) \mathrm{Cl}$ ID cell population grown in the presence of $30 \mu \mathrm{g} \mathrm{BrdU} / \mathrm{ml}$ (Attardi \& Attardi, 1972). These observations had indicated that thymidilate synthetase activity is still present in cells exposed to a high concentration of the halogenated precursor, and furthermore had pointed to differences 


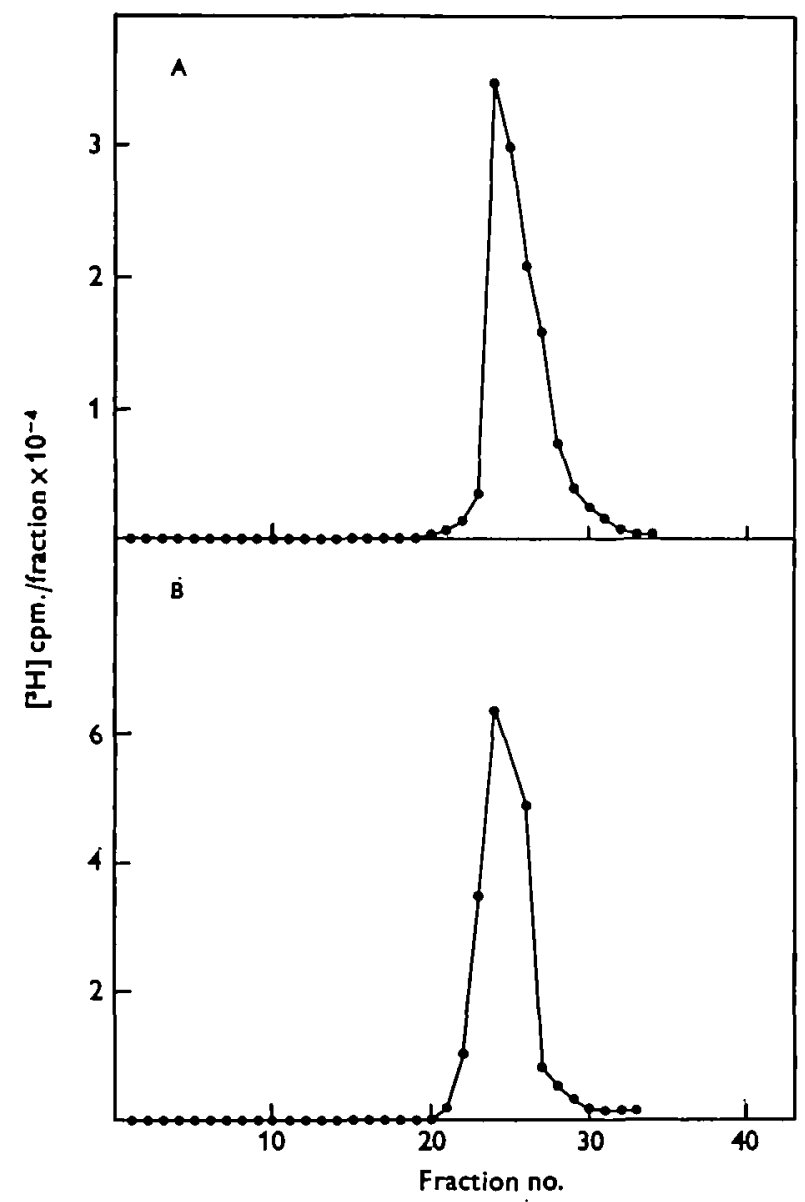

Fig. 8. Buoyant density distribution in a $\mathrm{CsCl}$ density gradient of total cell DNA from BrdU-grown $\mathrm{LM}\left(\mathrm{TK}^{-}\right) \mathrm{Cl}$ ID cells long-term labelled with $\left[5^{-3} \mathrm{H}\right] \mathrm{deoxy}-$ cytidine and irradiated with 'visible' light for $48 \mathrm{~h}(\mathrm{~B})$, and from the corresponding non-irradiated control (A).

from cell to cell, or even from mitochondrion to mitochondrion, in mitochondrionassociated thymidine kinase activity and/or in thymidilate synthetase activity, or to a cellular variability in permeability to the analogue.

In the present work, BrdU incorporation into mit-DNA has been found to be markedly reduced if the cells were at high concentration during their exposure to the halogenated precursor or during the previous several generations of growth. It is not known whether this phenomenon depends on changes in the rate of synthesis or activity of the mitochondrial thymidine kinase and/or of the thymidilate synthetase or on changes in cell permeability.

Damage and destruction of mitochondrial DNA in irradiated BrdU-grown $\mathrm{Cl}$ iD cells

In the accompanying paper (Attardi et al. I975), evidence has been presented indicating that irradiation with 'visible' light of $\mathrm{Cl} \mathrm{ID}$ cells grown in the presence or 
absence of BrdU causes a substantial decrease in their growth rate in mass culture and an exponential decline in their clone-forming capacity, with a half-life of $2-3 \mathrm{~h}$, after a lag of a few hours, the effects being somewhat more pronounced in BrdU-grown cells. Furthermore, the data showed a striking phenomenon of reversal of this BrdUindependent light damage as a result of trypsinization and transfer of the cells to fresh medium after irradiation.

The results obtained in the present work have indicated clearly that the residual, non-reversible light damage which can be detected specifically, after trypsinization and replating, in BrdU-grown cells as an exponential loss of cloning efficiency with a half-life of $8 \mathrm{~h}$, involves mit-DNA. In fact, after irradiation with 'visible' light, progressive damage and destruction of mit-DNA have been observed in BrdUgrown $\mathrm{Cl}$ ID cells, but not in cells grown in the absence of the halogenated precursor. For a matter of convenience, most of the experiments reported here have been carried out by examining either the fate of the pre-existing, long-term labelled mit-DNA, or the capacity of this DNA to replicate, directly in irradiated cultures, without trypsinization and replating. However, a few pulse-labelling experiments performed on cultures trypsinized and replated after irradiation have given similar results.

The damage to the pre-existing, long-term labelled mit-DNA during irradiation with 'visible' light of $\mathrm{BrdU}$-grown $\mathrm{Cl}$ ID cells was revealed, at first, by a decrease in the proportion of closed-circular mit-DNA and increase in that of open-circular mit-DNA, indicating the occurrence of single-strand nicks (the labelled material which accumulates in the trough between components I and II of monomeric mitDNA in the 2-step $\mathrm{CsCl} /$ ethidium bromide gradients presumably represents, in its majority, fully open concatenated oligomers), and, later, by the appearance of components which sediment more slowly than form I of mit-DNA and probably represent fragments of mit-DNA. The destruction of mit-DNA was indicated by the decrease in the amount of total mit-DNA which occurs after the first $\mathrm{I} 8 \mathrm{~h}$ of irradiation.

The damage and destruction of mit-DNA in BrdU-grown $\mathrm{Cl}$ ID cells exposed to 'visible' light were also revealed by the rapid decline in the amount of mit-DNA pulse-labelled with the tritiated precursor after irradiation. In fact, there was a fast decrease of pulse-labelled mit-DNA to a level of about $50 \%$ in the first $12 \mathrm{~h}$, followed, in the next $48 \mathrm{~h}$, by a slower decline to a level of about $25 \%$. It should be noticed that the ${ }^{3} \mathrm{H}$ pulse-labelling data were normalized only for differences in the number of cells in different samples; since there was almost a doubling in size of the irradiated cells during the first $24 \mathrm{~h}$, any replication of mit-DNA accompanying the increase in cell mass would have increased the number of templates for replication, thereby decreasing the apparent effect of irradiation on mit-DNA replication. Qualitatively, the pattern of pulse-labelled mit-DNA in the 2-step CsClgradient remained fairly normal even after $24 \mathrm{~h}$ exposure of the cells to light. This result is in agreement with the idea that, during the first $24 \mathrm{~h}$ of irradiation, only the undamaged molecules undergo replication. The qualitative alterations in profile detectable after 48- or $60-\mathrm{h}$ irradiation may reflect an anomalous replication process occurring in damaged molecules after prolonged exposure of the cells to light. 
That the damage of mit-DNA observed in the present work in irradiated, BrdUgrown $\mathrm{Cl} \mathrm{ID}$ cells is due to the incorporation of BrdU into this DNA, and not to a secondary effect of the exposure of the cells to the halogenated precursor, is strongly suggested by the observation that no damage of mit-DNA was observed when growth in the presence of $\mathrm{BrdU}$ occurred under conditions where this analogue was not incorporated into DNA. Also the failure to observe any obvious gross damage of nuclear DNA, which does not incorporate, or incorporates only to a minimal extent, $\mathrm{BrdU}$, is consistent with the above interpretation. The destruction of mit-DNA occurring after prolonged irradiation is very likely due to the action of nucleases on damaged molecules.

Relationship between damage of mitochondrial DNA and loss of cell viability in irradiated, $B r d U$-grown $\mathrm{Cl} 1 \mathrm{D}$ cells

The $\left[5^{-3} \mathrm{H}\right]$ deoxycytidine pulse-labelled mit-DNA profiles in the 2-step $\mathrm{CsCl} /$ ethidium bromide gradients suggest that, during the first $24 \mathrm{~h}$ irradiation of BrdUgrown $\mathrm{Cl}$ ID cells, only, or predominantly, intact mit-DNA molecules replicate. Therefore, the quantitative behaviour of the pulse-labelled mit-DNA during this period, normalized for the increase in cell number, should reflect fairly closely, in the absence of precursor pool effects, the changes in the amount per cell of undamaged mit-DNA molecules. As mentioned above, at any time during the exposure of the cells to light, these undamaged molecules would include molecules present at the beginning of irradiation and which did not replicate, as well as, probably, molecules which replicated during irradiation, prior to the pulse. As a matter of fact, because of the doubling of the average size of the irradiated cells during the first $24 \mathrm{~h}$, it is not unreasonable to think that during this period intact mit-DNA molecules would replicate in proportion to the cell mass increase. In the present experiments, it was found that the amount of pulse-labelled mit-DNA declined to about $50 \%$ after I 2-h irradiation. After longer irradiation times, the amount of pulse-labelled mitDNA declined more slowly; this is possibly due to the above-mentioned increase in mit-DNA templates accompanying the cell size increase and, after $24 \mathrm{~h}$ irradiation, to the anomalous replication of damaged mit-DNA molecules suggested by the 2-step $\mathrm{CsCl} /$ ethidium bromide gradient patterns. If one limits the analysis to the first $\mathrm{I} 2 \mathrm{~h}$ of irradiation, during which these complications should affect less the interpretation of the results, it would appear that during this period the decrease in the amount of intact mit-DNA in irradiated cells parallels fairly closely the loss of cloning efficiency of the cells exposed to 'visible' light. This result strongly suggests that damage and destruction of mit-DNA may be responsible for the loss of cell viability; however, the precise quantitative aspects of the relationship between the 2 phenomena would remain to be defined.

As mentioned in the accompanying paper (Attardi et al. 1975), the above conclusion of the involvement of mit-DNA in the killing effect of 'visible' light is not in disagreement with the single-hit shape of the curve illustrating the loss of cell cloning efficiency during irradiation; in fact, a similar situation has been shown to occur for petite induction in yeast (Sherman, 1959; Sugimura, Okabe \& Imamura, 1966; 
Slonimski, Perrodin \& Croft, I968; Wilkie, I963; Maroudas \& Wilkie, I968), where the number of targets appears to be much smaller than the number of mitochondrial DNA molecules per cell. The molecular basis of this phenomenon is still unknown.

This work was supported by USPHS grant No. GM-I I 726. B.C. was supported by a Gosney Fellowship and the Centre National de la Recherche Scientifique, France.

\section{REFERENCES}

ATtard, B. \& ATTARDi, G. (1972). Fate of mitochondrial DNA in human-mouse somatic cell hybrids. Proc. natn. Acad. Sci. U.S.A. 69, 129-133.

Attardi, G., Keelexy, B. \& Tu, C. (I975). Photosensitivity and heat resistance conferred by BrdU incorporation upon a thymidine kinase-deficient mouse cell line with persistent mitochondrial enzyme activity. F. Cell Sci. 19, 55-68.

Marmur, J. (I96I). A procedure for the isolation of deoxyribonucleic acid from microorganisms. 7. molec. Biol. 3, 208-2 I8.

Maroudas, N. G. \& Wilkie, D. (1968). Ultraviolet irradiation studies on the cytoplasmic determinant of the yeast mitochondrion. Biochim. biophys. Acta 166, 68 I-688.

NAss, M. M. K. (1 969). Motochondrial DNA. I. Intramitochondrial distribution and structural relations of single- and double-length circular DNA. f. molec. Biol. 42, 521-528.

Puck, T. T. \& KaO, F. T. (I967). Genetics of somatic mammalian cells. V. Treatment with 5-bromodeoxyuridine and visible light for isolation of nutritionally deficient mutants. Proc. natn. Acad. Sci. U.S.A. 58, $1227-1234$.

Sherman, F. (1959). The effects of elevated temperatures on yeast. II. Induction of respiratorydeficient mutants. F. cell. comp. Physiol. 54, 37-52.

Slonimski, P. P., Perrodin, G. \& Croft, J. H. (1968). Ethidium bromide induced mutation of yeast mitochondria: Complete transformation of cells into respiratory deficient nonchromosomal 'petites'. Biochem. Biophys. Res. Commun. 30, 232-239.

SMith, C. A., Jordan, J. M. \& Vinograd, J. (I97I). In vivo effects of intercalating drugs on the superhelix density of mitochondrial DNA isolated from human and mouse cells in culture. F. molec. Biol. 59, 255-272.

Storrie, B. \& AtTARdi, G. (I972). Expression of the mitochondrial genome in HeLa cells. XIII. Effect of selective inhibition of cytoplasmic or mitochondrial protein synthesis on mitochondrial nucleic acid synthesis. f. molec. Biol. 7r, I77-199.

Sugimura, T., Okabe, K. \& Imamura, A. (Ig66). Number of cytoplasmic factors in yeast cells. Nature, Lond. 212, 304.

SzYBALSKI, W. \& OPARA-KuBINSKA, Z. ( 1965 ). Radiobiological and physicochemical properties of 5-bromodeoxyuridine-labeled transforming DNA as related to the nature of the critical radiosensitive structures. In Cellular Radiation Biology, pp. 225-240. Baltimore: Williams and Wilkins.

WILKIE, D. $\left(\mathrm{I}_{96} 6_{3}\right)$. The induction by monochromatic UV light of respiratory-deficient mutants in aerobic and anaerobic cultures of yeast. 7 . molec. Biol. 7, 527-533.

(Received 24 March 1975) 